\title{
Review of Processing Technologies for Spent Zinc Batteries
}

Katarína Blašková, Jarmila Trpčevská, Tomáš Vindt

Faculty of Metallurgy, Technical University in Košice, Letná 9, 04200 Košice. Slovak Republic. E-mail: katarina.blaskova@tuke.sk,jarmila.trpcevska@tuke.sk, tomas.vindt@tuke.sk

This paper deals with the possibility of spent portable batteries treatment with the aim of zinc recovery. Perspective of pyrometallurgical and hydrometallurgical process is described. Samples of zinc based portable batteries were submitted under the investigation. Aim of the work was to find the best conditions for zinc recovery. Experimental work focused on hydrometallurgical process was conducted. Results have shown $100 \%$ zinc recovery under these conditions: leaching in medium $2 \mathrm{M}\left(\mathrm{NH}_{4}\right)_{2} \mathrm{CO}_{3}$, addition of $20 \mathrm{ml}$ of $\mathrm{NH}_{4} \mathrm{OH}$ as reductant, leaching temperature $20^{\circ} \mathrm{C}$, within 10 minutes.

Keywords: spent zinc batteries, hydrometallurgy, leaching.

\section{Acknowledgements}

This work was supported by a grant from the Slovak National Grant Agency under the VEGA Project 1/0425/14.

\section{References}

[1] YANG, L., and al. (2015). Recovery of Co, Mn, Ni, and Li from spent lithium ion batteries for the preparation of LiNixCoyMnzO2 cathode materials, Ceramics International, Volume 41, 11498-11503.

[2] YANG, Y., and al. (2015). Thermal treatment process for the recovery of valuable metals from spent lithium-ion batteries, Hydrometallurgy.

[3] NOGUEIRA, C. A., MARGARIDO, F. (2015). Selective process of zinc extraction from spent Zn-MnO2 batteries by ammonium chloride leaching, Hydrometallurgy, Volume 157,13-21.

[4] ROSSINI, G., BERNARDES, A. E. (2006). Galvanic sludge metals recovery by pyrometallurgical and hydrometallurgical treatment, Journal of Hazardous Materials, Volume 131, 210-216.

[5] SAYILGAN. E. (2009). A review of technologies for the recovery metals from spent alkaline and zinc-carbon batteries, vedecký výskum, Hydrometalurgia, 97, 158 - 166.

[6] ESPINOSA, D., BERNARDES, A. (2004). An overview on the current processes for the recycling of batteries, Journal of Power Sources, 135, 311-319.

[7] SAYILGAN. E. (2009) A review of technologies for the recovery metals from spent alkaline and zinc-carbon batteries, Hydrometalurgy, 97, 158 - 166.

[8] BERNARDES, A., ESPINOSA, D. (2004). Recycling of batteries: a review of current processes and technologies, Journal of Power sources, 130, 291-298).

[9] Batérie [online]. Dostupné na ineternete:http://batteryuniversity.com/learn/article/primary_batteries [citované 18.10. 2013].

[10]ORÁČ, D., VINDT, T. (2014). Druhotné suroviny a odpady, návody na cvičenia, Košice, IBAN 978-80-553-16444.

[11]CARSTEN, H. (2014). Recovery of Zinc from Spent Batteries by the Treatment in a Shaft Furnace, Erzmetall World of Metallurgy, 67/2014 No.4, GDMB Verlag GmbH, ISSN 1613-2394.

[12]Division of primary and secondary cells [online]. Available on the ineternet: http://www.separujodpad.sk/index.php/obcan/ako-separovat/baterie-aakumulatory.Html.

[13] VELOSO, L. a kol. (2005). Development of a hydrometallurgical route for the recovery of zinc and manganese from spent alkaline batteries, Journal of Power Sources 152, 295 - 302.

[14]DE MICHELIS, I. a kol. (2007). Recovery of zinc and manganese from alkaline and zinc carbon spent batteries, vedecký výskum, Journal of Power Sources 172, 975 - 983.

[15] MARTA DE SOUZA, C. a kol. (2001). Characterization of used alkaline batteries powder and analysis of zinc recovery by acid leaching, Journal of Power Sources 103, 120 - 126.

[16]FREITAS, M. a kol. (2007). Recycling manganese from spent $\mathrm{Zn}$ - MnO2 primary batteries, Journal of Power Sources 164. $947-952$. 